\title{
ERRATUM
}

\section{Teacher Education for the Changing Demographics of Schooling}

\section{Issues for Research and Practice}

\section{Lani Florian and Nataša Pantić}

(C) Springer International Publishing AG 2017

L. Florian, N. Pantić (eds.), Teacher Education for the Changing Demographics of Schooling, Inclusive Learning and Educational Equity 2, DOI 10.1007/978-3-319-54389-5

DOI 10.1007/978-3-319-54389-5_17

The original version of this book was published with incorrect affiliations for Dr. Lani Florian and Dr. Nataša Pantić. They have been corrected and updated as:

Lani Florian, Moray House School of Education, University of Edinburgh, Edinburgh, UK

Nataša Pantić, Moray House School of Education, University of Edinburgh, Edinburgh, UK 